\title{
ASSESSMENT OF HEAVY METAL CONCENTRATION IN FEATHERS OF ARMENIAN GULL (LARUS ARMENICUS BUTURLIN, 1934) AND WATER SAMPLES OF HAZAR LAKE, TURKEY
}

\author{
NERGiz, H. ${ }^{*}$ - ŞAMAT, A. K. \\ Bitlis Eren University, Faculty of Scince and Art, Department of Biology, Bitlis 13000, Turkey \\ ${ }^{*}$ Corresponding author \\ e-mail: humeyranergiz@gmail.com; phone: +90-434-222-0020
}

(Received 23 $3^{\text {rd }}$ Apr 2019; accepted $4^{\text {th }}$ Jul 2019)

\begin{abstract}
Accumulation levels of heavy metals in the feathers of birds reflect the abundance of these pollutants in the medium and birds can be useful indicators of this kind of pollution. The aim of the present study was to detected levels of some heavy metals of juvenile and adult Armenian Gull (Larus armenicus) and in the surface water of Hazar Lake, Turkey. The feather samples from different parts of the bodies of dead adult and juvenile Armenian Gulls were collected. Water samples were taken from different sampling stations distributed across the lake. Heavy metal concentrations were measured using a Thermo Scientific ICAP 600 Spectrometer. There was no significant statistical difference for bioaccumulation of heavy metals and trace elemets in adult and juvenile gull feathers ( $p>0.05)$. However, the highest metal concentrations were measured in juveniles. The highest average residue amounts in juvenile cover feathers were $0.02 \mathrm{mg} / \mathrm{kg} \mathrm{Cd}, 0.46 \mathrm{mg} / \mathrm{kg} \mathrm{Pb}, 0.72 \mathrm{mg} / \mathrm{kg} \mathrm{Cu}, 58,31 \mathrm{mg} / \mathrm{kg} \mathrm{Fe}, 0.04 \mathrm{mg} / \mathrm{kg}$ $\mathrm{Ni}, 8.38 \mathrm{mg} / \mathrm{kg} \mathrm{Zn}, 0.07 \mathrm{mg} / \mathrm{kg} \mathrm{Se}, 1.3 \mathrm{mg} / \mathrm{kg} \mathrm{Mn}, 0.005 \mathrm{mg} / \mathrm{kg} \mathrm{Cr}$ and $0.01 \mathrm{mg} / \mathrm{kg}$ As. Mean values of all metals were within the acceptable limits of normal values for waterbirds, except $\mathrm{Pb}$ and $\mathrm{Mn}$. When we evaluated the findings heavy metal concentration of the water were detected decrease in sequence of; $\mathrm{Fe}>\mathrm{As}>\mathrm{Zn}>\mathrm{Ni}>\mathrm{Cd}>\mathrm{Cu}>\mathrm{Cr}>\mathrm{Pb}>\mathrm{Mn}>\mathrm{Se}$. Compared with WHO (World Health Organization) and TSE-266 (Turkish Standarts Institution) standards; $\mathrm{Cd}, \mathrm{Cu}, \mathrm{Zn}$ and $\mathrm{Cr}$ concentrations in water were higher than the permissible levels for drinking water. It seems Armenian Gull feathers are useful monitoring tool for assessing heavy metal contamination.
\end{abstract}

Keywords: bioindicator, biomonitoring, birds, toxic effect, wetland

\section{Introduction}

Environmental degradation of wetland ecosystems by metals is a worldwide problem because of their toxic effects and long persistence (Mansouri et al., 2012; Klaassen, 2013; Zhang et al., 2018). As the trophic level rises in a food chain, the amount of toxic pollutant build up increases and therefore they involve great threat for all species and ecosystems (Ullah et al., 2014).

Indicator species are used to biomonitor environmental changes and to assess effects of pollution. Birds have been recognized as the useful bioindicators of environmental health (Erwin and Custer, 2000). They can be exposed to heavy metals through intake of food, drinking contaminated water and by physical contact (Becker, 2003; Burger and Gochfeld, 2004; Bostan et al., 2007).

One of the suitable methods of assessing level of the metal pollution in natural habitats is to determine the amount of it in bird feathers. Especially birds of prey species occupying higher trophic levels deemed indicative for bioaccumulation in the whole food chain (Boncompagni et al., 2003; Barbieri et al., 2010). Gulls are top predator species of their food web and they can give information about a large area around sampling site. 
The Armenian Gull (L. armenicus) breeds in eastern Turkey, Armenia, southern Georgia and northwestern Iran. It is known that breeding population of species in Turkey has declined rapidly in recent years (Adızel et al., 2010; Nergiz and Durmuş, 2017; Durmuş et al., 2018). There is one known crowded native resident population of Armenian Gull in Hazar Lake in East Anatolia. But studies about Hazar Lake population of the species are scanty.

In this study, we measured levels of $\mathrm{Cd}, \mathrm{Pb}, \mathrm{Cu}, \mathrm{Fe}, \mathrm{Ni}, \mathrm{Zn}, \mathrm{Se}, \mathrm{Mn}, \mathrm{Cr}$ and $\mathrm{As}$ in feathers of L. armenicus and water samples of its foraging areas at Hazar Lake. The objectives of this study were was to assess relationships between the metal levels in the feather of adult and juvenile Armenian Gulls and to compare the concentration of these metals in feathers of the species and their habitat at Hazar Lake, Turkey. We hope that this study will be a useful reference for the determination of regional contamination and realization of a protection plan for this bioindicator species.

\section{Materials and methods}

Feather samples of Armenian Gull were collected during 2015-2016 breeding season from the dead individuals in Hazar Lake. Water samples $(n=48)$ were taken once a month at sampling station distributed across the lake. The details of each sampling station are given in Figure 1. Collected specimens were labeled and transported to the laboratory under appropriate conditions.

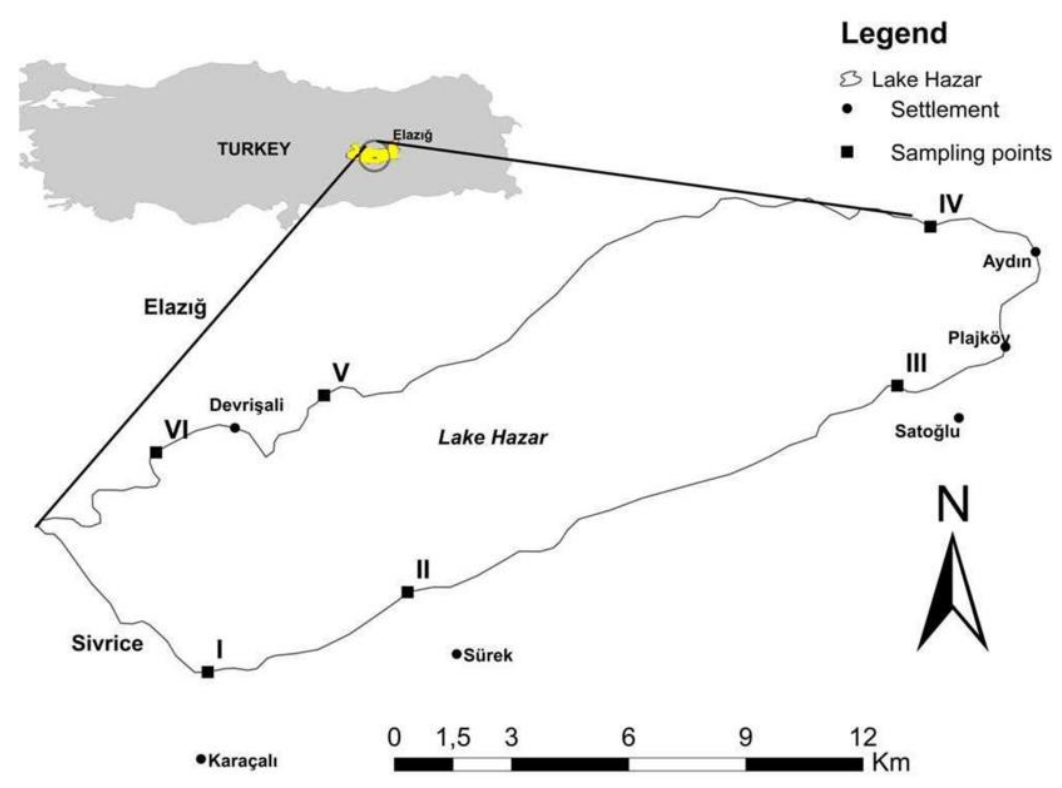

Figure 1. Location of sampling stations in Lake Hazar

Surface water samples were taken from $50 \mathrm{~cm}$ below the water surface using $100 \mathrm{ml}$ sterile bottles, filtered and acidified with $1 \mathrm{ml}$ of concentrated $\mathrm{HNO}_{3}$ and then kept in a freezer at $4^{\circ} \mathrm{C}$ until measured. Total 40 feather samples from different parts of the bodies of adult and juvenile Armenian Gulls were collected (APF: Adult Primary Wing Feather; ASF: Adult Secondary Wing Feather; ACF: Adult Cover Feather; JCF: Juvenile Cover Feather). Samples of feather transferred to the laboratory were washed with deionized water and rinsed with acetone to wash away the organic materials which 
the water cannot dissolve. All samples were dried at $60^{\circ} \mathrm{C}$ for $24 \mathrm{~h}$ to remove moisture. The dried feather samples were cut into small pieces with a steel scissors. $0.2 \mathrm{~g}$ (dry weight) from each sample were put into glass dissolution vessels and $5 \mathrm{ml} \mathrm{HNO}_{3}(65 \%)$ added to each, and stored at room temperature for $24 \mathrm{~h}$. The samples were heated to boiling on a hot plate until the color vapors of the samples vanished slowly and they were completely mineralized. After this, all samples were diluted to $10 \mathrm{ml}$ with deionized water. Each sample was analysed at least three times for $\mathrm{Cd}, \mathrm{Pb}, \mathrm{Cu}, \mathrm{Fe}, \mathrm{Ni}$, $\mathrm{Zn}, \mathrm{Se}, \mathrm{Mn}, \mathrm{Cr}$ and As using ICP-AAS (Thermo Scientific ICAP 600 series).

\section{Statistical analysis}

All metal concentrations were detected as milligrams per liter for water samples and on a dry weight basis as milligrams per gram for feather samples. For this reason, average heavy metal levels were calculated as milligrams per kilogram. Statistical analysis was conducted in order to assess and compare the average values of metals in L. armenicus. Data were analyzed with SPSS software (Version 23). The average distribution of metals in L. armenicus (adults and juveniles) and water samples were assessed with independent t-test.

\section{Results and discussion}

The distribution of heavy metal and trace elements in feathers of L. armenicus for adults and juveniles respectively are given in Table 1. Results of our work confirm the findings by Burger (1993), Boncompagni et al. (2003) and Malik and Zeb (2009) that heavy metals pile up at different concentrations in feathers of adult and juvenile birds.

Table 1. Concentrations of heavy metals and trace elements in feathers ( $\mathrm{mg} / \mathrm{kg}$ dry weight) of L. armenicus and in water samples of Hazar Lake $(\mathrm{mg} / \mathrm{l})$

\begin{tabular}{c|c|c|c|c}
\hline Metal & $\begin{array}{c}\text { Adults } \\
\text { Mean } \pm \text { SD }\end{array}$ & $\begin{array}{c}\text { Juveniles } \\
\text { Mean } \pm \text { SD }\end{array}$ & $\begin{array}{c}\text { Water samples } \\
\text { Mean } \pm \text { SD }\end{array}$ & p \\
\hline $\mathrm{Cd}$ & $0.0207 \pm 0.0185$ & $0.0265 \pm 0.0294$ & $0.0091 \pm 0.0266$ & 0.56 \\
$\mathrm{~Pb}$ & $0.4491 \pm 0.4162$ & $0.4689 \pm 0.2592$ & $0.0046 \pm 0.01152$ & 0.88 \\
$\mathrm{Cu}$ & $0.6302 \pm 0.1445$ & $0.7295 \pm 0.1755$ & $0.0081 \pm 0.0418$ & 0.082 \\
$\mathrm{Fe}$ & $24.0938 \pm 19.3146$ & $58.3160 \pm 15.0129$ & $0.0697 \pm 0.1685$ & 0.06 \\
$\mathrm{Ni}$ & $0.0063 \pm 0.0143$ & $0.0490 \pm 0.1321$ & $0.0101 \pm 0.03519$ & 0.08 \\
$\mathrm{Zn}$ & $7.2498 \pm 1.7706$ & $8.3848 \pm 1.9769$ & $0.0146 \pm 0.0432$ & 0.09 \\
$\mathrm{Se}$ & $0.0598 \pm 0.0289$ & $0.0754 \pm 0.0238$ & $* \mathrm{BDL}$ & 0.09 \\
$\mathrm{Mn}$ & $0.6212 \pm 0.4237$ & $1.3006 \pm 0.3392$ & $0.003 \pm 0.0055$ & 0.07 \\
$\mathrm{Cr}$ & $0.0041 \pm 0.0125$ & $0.0057 \pm 0.0134$ & $0.0077 \pm 0.0418$ & 0.18 \\
$\mathrm{As}$ & $0.0049 \pm 0.0037$ & $0.0165 \pm 0.0311$ & $0.0175 \pm 0.0032$ & 0.25 \\
\hline
\end{tabular}

*BDL: Below Detection Limit, statistically significance was accepted at $\mathrm{p}<0.05$

Some studies have been conducted on heavy metals levels in feather of birds. Barbieri et al. (2010) showed that the levels of $\mathrm{Cd}, \mathrm{Co}, \mathrm{Cr}, \mathrm{Mn}, \mathrm{Ni}, \mathrm{Zn}$, and $\mathrm{Pb}$ increased with age. Furthermore, Burger (1996) indicated that the ratio of cadmium and lead in feathers of Franklin's gulls were lower in juveniles. Mansouri et al. (2012) pointed out that metal levels were always higher in adults, because of the age-related bioaccumulation. In the contrast, several studies have reported that there are significant differences in metal contamination in feathers with age related in which chicks had 
significantly higher concentration of metal than adults (Stewart et al., 1997; Dauwe et al., 2000; Burger and Gochfeld, 2009; García-Tarrasón et al., 2013).

Present study provides additional supports for the suggestions by Burger et al. (2008) and Movalli (2000), that there was no significant statistical difference between feather samples taken from adults and juveniles for bioaccumulation of heavy metal and trace elements $(p>0.05)$. The average levels of heavy metals detected in juvenile feathers in the present study were as; $\mathrm{Cd} 0.02 \mathrm{mg} / \mathrm{kg}, \mathrm{Pb} 0.46 \mathrm{mg} / \mathrm{kg}, \mathrm{Cu} 0.72 \mathrm{mg} / \mathrm{kg}, \mathrm{Fe}$ $58.316 \mathrm{mg} / \mathrm{kg}$, Ni $0.04 \mathrm{mg} / \mathrm{kg}$, Zn $8.38 \mathrm{mg} / \mathrm{kg}$, Se $0.07 \mathrm{mg} / \mathrm{kg}, \mathrm{Mn} 1.3 \mathrm{mg} / \mathrm{kg}, \mathrm{Cr}$ $0.005 \mathrm{mg} / \mathrm{kg}$ and As $0.01 \mathrm{mg} / \mathrm{kg}$. The chemical profiles of juveniles were as follows: $\mathrm{Fe}>\mathrm{Zn}>\mathrm{Mn}>\mathrm{Cu}>\mathrm{Pb}>\mathrm{Se}>\mathrm{Cd}>\mathrm{As}>\mathrm{Ni}>\mathrm{Cr}$. The highest trace metal concentrations were measured in juveniles. But the differences were smaller (Figure 2). This age related differences may be due to diet differences. Juveniles may have foraged in different habitats and fed more often than adults would have higher levels of metals in their feathers. The high levels of heavy metal accumulation in juveniles can be correlated with the egg and their food, which is derived locally.

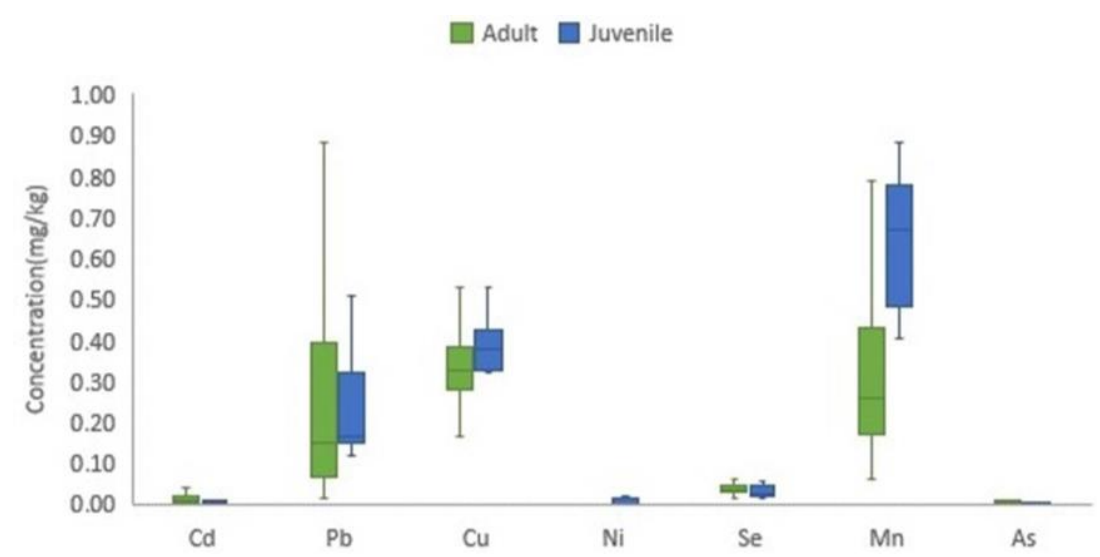

Figure 2. Comparison of heavy metals in the feather samples taken from adult and juvenile Armenian Gulls

$\mathrm{Pb}$ and $\mathrm{Mn}$ levels measured in present study were higher than those reported in previous researches. In the literature, an average of $0.51 \mathrm{ppm} \mathrm{Mn}$ and $0.19 \mathrm{ppm} \mathrm{Cd}$ was detected for marine birds (Burger, 2002). These values are much lower than that measured in our study. Greater than $2 \mathrm{mg} / \mathrm{kg}$ (dw) Cd, $4 \mathrm{mg} / \mathrm{kg}(\mathrm{dw}) \mathrm{Pb}, 1200 \mathrm{mg} / \mathrm{kg}$ (dw) Zn, $2.8 \mathrm{mg} / \mathrm{kg}$ (dw) Cr, $26 \mathrm{mg} / \mathrm{kg}$ (dw) Se, $0.96 \mathrm{mg} / \mathrm{kg}$ (dw) As concentrations in feathers were considered as abnormal poisoning and indicates increased environmental pollution (Burger, 1993; Heinz, 1996; Burger and Gochfeld, 2000; Taggart et al., 2006; Nighat, 2013). In the present study, mean heavy metal and trace element levels during 2015/2016 were in order of magnitude below known toxic effect levels.

Durmuş et al. (2018) studied metal deposition ( $\mathrm{Mg}, \mathrm{Zn}, \mathrm{Cu}, \mathrm{Mn}, \mathrm{Li}, \mathrm{Sn}, \mathrm{Co}$ and $\mathrm{Se}$ ) in feathers of the Armenian Gull from various regions of Van Lake Basin in Turkey. We found the mean concentration of $\mathrm{Cr}$ to be lower than their results but $\mathrm{Zn}, \mathrm{Mn}$ and $\mathrm{Se}$ concentrations were slightly higher in our study which might be due to different nutrient density.

The heavy metal levels in water are given in Table 1. The mean values revealed that accumulation levels of heavy metals and trace elements in water varied from each other depending on the different sampling site. $\mathrm{Pb}, \mathrm{Fe}, \mathrm{Zn}$ and As were noted in all seasons. 
Among the analyzed metals Fe was the highest and Se was the lowest metal which was below detection limit in all seasons while $\mathrm{Cd}$ and $\mathrm{Cr}$ were recorded only in autumn and winter, $\mathrm{Mn}$ in winter, $\mathrm{Cu}$ and $\mathrm{Ni}$ in summer, autumn and winter. There were no statistically significant differences in the concentration of metal among seasons ( $\mathrm{p}>0.05$ ). The highest levels of $\mathrm{Cu}, \mathrm{Cr}, \mathrm{Fe}, \mathrm{Mn}, \mathrm{Ni}$, and $\mathrm{Zn}$ were noted during spring, $\mathrm{Cd}$ and $\mathrm{Pb}$ in summer and autumn (Table 2).

The heavy metal and trace elements accumulation in water decreased in the following order; $\mathrm{Fe}>\mathrm{As}>\mathrm{Zn}>\mathrm{Ni}>\mathrm{Cd}>\mathrm{Cu}>\mathrm{Cr}>\mathrm{Pb}>\mathrm{Mn}>\mathrm{Se}$. The highest $\mathrm{Fe}(1.29 \mathrm{mg} / \mathrm{l})$, As $(0.03 \mathrm{mg} / \mathrm{l}), \mathrm{Zn}(0.28 \mathrm{mg} / \mathrm{l}), \mathrm{Ni}(0.18 \mathrm{mg} / \mathrm{l})$ levels were in sites 4 and 5 . The highest heavy metal concentrations in the two sampling sites were associated with natural sources and human related activities.

Table 2. The concentrations ( $\mathrm{mg} / \mathrm{l})$ of some heavy metals in Hazar Lake

\begin{tabular}{c|c|c|c|c|c|c|c|c|c|c}
\hline Season & $\mathbf{C d}$ & $\mathbf{P b}$ & $\mathbf{C u}$ & $\mathbf{F e}$ & $\mathbf{N i}$ & $\mathbf{Z n}$ & $\mathbf{S e}$ & $\mathbf{M n}$ & $\mathbf{C r}$ & $\mathbf{A s}$ \\
\hline Spring & 0.01 & 0.001 & 0.03 & 0.11 & 0.04 & 0.03 & $* \mathrm{BDL}$ & 0.005 & 0.03 & 0.01 \\
Summer & 0.02 & 0.001 & *BDL & 0.06 & *BDL & 0.001 & *BDL & 0.004 & 0.0002 & 0.01 \\
Autumn & *BDL & 0.01 & *BDL & 0.1 & *BDL & 0.006 & *BDL & 0.002 & $*$ BDL & 0.01 \\
Winter & *BDL & 0.005 & *BDL & 0.1 & *BDL & 0.01 & *BDL & *BDL & *BDL & 0.01 \\
\hline
\end{tabular}

*BDL: Below Detection Limit

We compared the results of heavy metals in water of Hazar Lake with WHO and TSE-266 standards. According to these standards, $\mathrm{Cu}, \mathrm{Zn}$ and $\mathrm{Cr}$ were higher than the permissible levels for drinking water in spring while Cd was in spring and summer.

Özmen et al. (2014) researched level of bioaccumulation of heavy metal and trace elements in water of Hazar Lake and recorded following highest concentrations (in $\mathrm{mg} / \mathrm{l}) \quad 0.43 \pm 0.11 \mathrm{Fe}, 0.071 \pm 0.018 \mathrm{Zn}, 0.012 \pm 0.002 \mathrm{Ni}, 0.025-0.22 \mathrm{Cu}$. Their results indicated that a general absence of serious pollution caused by heavy metals such as $\mathrm{Cd}$, $\mathrm{Pb}$ and $\mathrm{As}$ in the lake. Alp et al. (2011) reported that $\mathrm{Cr}, \mathrm{Pb}$ and $\mathrm{Cd}$ levels were below detection limit in all seasons. According to our results the heavy metal concentrations of Hazar Lake' water increased which is presumed to be because of increased anthropological pressures.

\section{Conclusions}

Present study, we assessed the concentration of heavy metal and trace elements in feathers of Armenian gull, resident in the eastern Anatolia region of Turkey and breeding on Hazar Lake, for which scarce information existed. The results provide evidence that feathers are efficient metarial to understand heavy metals pollution levels and bioaccumulation along the wetland food chain with higher concentrations found in bird feathers than water. Metal concentrations detected during the study were within the acceptable range of normal concentrations for waterbirds except for $\mathrm{Pb}$ and $\mathrm{Mn}$. Furthermore, the heavy metals $(\mathrm{Cd}, \mathrm{Cu}, \mathrm{Zn}, \mathrm{Cr})$ concentrations in water did exceeded WHO and TSE-266 guidelines in spring and summer. Although levels of heavy metals were not high, our results revealed that precautions need to be taken in order to prevent future heavy metal pollution in the lake basin. Consequently, we confirmed that feathers of Armenian Gull can reveal local contamination around the foraging and breeding sites and can be a very useful monitoring instrument for assessing heavy metal contamination. 
Acknowledgements. This study was supported by Bitlis Eren University, BEBAP 2015.02 project. We wish to thank to The Scientific Research Project Unit of Bitlis Eren University for their financial support.

\section{REFERENCES}

[1] Adızel, Ö., Durmuş, A., Kiziroğlu, İ. (2010): Preliminary study on newly detected Yayliyaka Marshes in the Lake Van Basin, Turkey. - The Journal of Animal and Plant sciences 20(4): 286-292.

[2] Alp, M. T., Şen, B., Özbay, Ö. (2011): Heavy metal levels in Cladophora glomerata which seasonally occurrence in the Lake of Hazar. - Ekoloji 8: 13-17.

[3] Barbieri, E., Passos, E. A., Filippini, A., Santos, I. S., Garcia, C. A. B. (2010): Assessment of trace metal concentration in feathers of seabird (Larus dominicanus) sampled in the Florianópolis, SC, Brazilian coast. - Environmental Monitoring and Assessment 169: 631-638.

[4] Becker, P. H. (2003): Trace metals and other contaminants in the environment. Biomonitoring with birds 6(19): 677-736.

[5] Boncompagni, E., Muhammad, A., Jabeen, R., Orvini, E., Gandini, C., Sanpera, C., Ruiz, X., Fasola, M. (2003): Egrets as monitors of trace-metal contamination in wetlands of Pakistan. - Archives of Environmental Contamination and Toxicology 45: 399-406.

[6] Bostan, N., Ashrif, M., Mumtaz, A. S., Ahmad, I. (2007): Diagnosis of heavy metal contamination in agro-ecology of Gujranwala, Pakistan using cattle egret as bioindicator. - Ecotoxicology 6: 247-251.

[7] Burger, J. (1993): Metals in avian feathers: Bioindicators of environmental pollution. Reviews in Environmental Contamination and Toxicology 5: 203-311.

[8] Burger, J. (1996): Heavy metal and selenium levels in feathers of Franklin's gulls in interior North America. - Auk 113: 399-407.

[9] Burger, J. (2002): Food chain differences affect heavy metals in bird eggs in Barnegat Bay, New Jersey. - Environmental Research 90: 33-39.

[10] Burger, J., Gochfeld, M. (2000): Metal levels in feathers of 12 species of seabirds from Midway Atoll in the northern Pacific Ocean. - Science of the Total Environment 257: 37 52 .

[11] Burger, J., Gochfeld, M. (2004): Metal levels in eggs of common terns (Sterna hirundo) in New Jersey: temporal trends from 1971 to 2002. - Environmental Research 94: 336343.

[12] Burger, J., Gochfeld, M. (2009): Comparison of arsenic, cadmium, chromium, lead, manganese, mercury and selenium in feathers in bald eagle (Haliaeetus leucocephalus), and comparison with common eider (Somateria mollissima), glaucous-winged gull (Larus glaucescens), pigeon guillemot (Cepphus columba), and tufted puffin (Fratercula cirrhata) from the Aleutian Chain of Alaska. - Environmental Monitoring and Assessment 152: 357-367.

[13] Burger, J., Gochfeld, M., Sullivan, K., Irons, D., McKnigh, A. (2008): Arsenic, cadmium, chromium, lead, manganese, mercury, and selenium in feathers of Black-legged Kittiwake (Rissa tridactyla) and Black Oystercatcher (Haematopus bachmani) from Prince William Sound, Alaska. - Science of the Total Environment 398: 20-25.

[14] Dauwe, T., Bervoets, L., Blust, R., Pinxten, R., Eens, M. (2000): Can Excrement and Feathers of Nestling Songbirds Be Used as Biomonitors for Heavy Metal Pollution? Archives of Environmental Contamination and Toxicology 39: 541-546.

[15] Durmuş, A., Çelik, E., Cenger, C., Taşkın, N., Acar, Ş. (2018): Determination of metals and selenium concentrations in feather of Armenian gull (Larus armenicus) living in Van Lake Basin, Turkey. - Applied Ecology and Environmental Research 16: 3831-3837.

[16] Erwin, M., Custer, T. W. (2000): Herons as indicators. - In: Kushlan, J. A., Hanfer, H. (eds.) Heron Conservation. Academic Press, San Diego. 
[17] García-Tarrasón, M., Pacho, S., Jover, L., Sanpera, C. (2013): Anthropogenic input of heavy metals in two Audouin's gull breeding colonies. - Marine Pollution Bulletin 74: 285-290.

[18] Heinz, G. H. (1996): Selenium in birds. - In: Beyer, W. M., Heinz, W. M. (eds.) Environmental Contaminants in Wildlife: Interpreting Tissue Concentrations. CRC Press: Boca Raton, FL, USA, pp. 447-458.

[19] Klaassen, C. (2013): Toxicology, The Basic Science of Poisons. - McGraw Hill Publishers, Newyork.

[20] Malik, R. N., Zeb, N. (2009): Assessment of environmental contamination using feathers of Bubulcus ibis L., as a biomonitor of heavy metal pollution, Pakistan. - Ecotoxicology 18: 522-536.

[21] Mansouri, B., Hoshyari, E., Pourkhabbaz, A., Babaei, H. (2012): Assessment of nickel levels in feathers of two bird species from southern Iran. - Podoces 7: 66-70.

[22] Movalli, P. A. (2000): Heavy metal and other residues in feathers of laggar falcon Falco biarmicus jugger from six districts of Pakistan. - Environmental Pollution 109: 267-275.

[23] Nergiz, H., Durmuş, A. (2017): Effects of habitat change on breeding water birds in Arin (Sodal1) Lake, Turkey. - Applied Ecology and Environmental Research 15: 1111-1118.

[24] Nighat, S., Iqbal, S., Nadeem, M. S., Mahmood, T., Shah, S. I. (2013): Estimation of heavy metal residues from the feathers of Falconidae, Accipitridae, and Strigidae in Punjab, Pakistan. - Turkish Journal of Zoology 37: 488-500.

[25] Özmen, H., Külahc1, F., Çukurovalı, A., Doğru, M. (2014): Concentrations of heavy metal and radioactivity in surface water and sediment of Hazar Lake (Elazı̆̆, Turkey). Chemosphere 55: 401-408.

[26] Stewart, F. M., Phillips, R. A., Catry, P., Furness, R. W. (1997): Influence of species, age and diet on mercury concentrations in Shetland seabirds. - Marine Ecology Progress Series 151: 237-244.

[27] Taggart, M. A., Figuerola, J., Green, A. J., Mateo, R., Deacon, C., Osborn, D., Meharg, A. A. (2006): After the Aznalcóllar mine spill: arsenic, zinc, selenium, lead and copper levels in the livers and bones of five waterfowl species. - Environmental Research 100: 349-361.

[28] Ullah, K., Hashmi, M. Z., Malik, R. N. (2014): Heavy-metal levels in feathers of cattle egret and their surrounding environment: a case of the Punjab province, Pakistan. Archives of Environmental Contamination and Toxicology 66: 139-153.

[29] Zhang, J., Han, L., Ji, Y., Wei, J., Cai, G., Gao, G., Wu, J., Yao, Z. (2018): Heavy metal investigation and risk assessment along the Le'An River from non-ferrous metal mining and smelting activities in Poyang, China. - Journal of Environmental Biology 39: 536545 . 